\title{
Perspectives on Poverty in Some Medieval French Literary Works
}

\author{
Glynnis M. Cropp \\ Massey University, Palmerston North, New Zealand
}

\begin{abstract}
In the sense of destitution, human wretchedness, and powerlessness, poverty is a permanent feature of medieval society, inescapable for many men and women. Some virtuous, self-denying people voluntarily chose a life of poverty, usually with a sense of advancing in Christian spirituality. Often associated in moral writing with covetousness, poverty figures among the vices to avoid. In literary works, some instances of poverty and its victims have acquired exemplary value, as is the case of Yvain's encounter with three hundred women silk workers in Chrétien de Troyes's 12th-century romance Le Chevalier au lion and its socio-economic implications. Two particular literary contexts are studied here: firstly, where poverty is a temporary condition, susceptible to change, that is improvement, by virtue of courtly-chivalrous action; and secondly, where poverty provides an effective means of disguise, despite possible dangers. While serving the narrative purpose, an ever-present aspect of reality was thus impressed on the audience.
\end{abstract}

Keywords: disguise, medieval French romance, poverty, treatment of the poor

\section{Introduction}

In the sense of destitution, human wretchedness, and powerlessness, poverty is a permanent feature of medieval society, inescapable for many men and women. It derives from inability to work and gain a livelihood, to keep oneself adequately clothed, fed, and housed, for decent, modest survival. Men and women suffer poverty, which exists in different degrees, with several thresholds, relative to social status, physical condition, and time and place. Historians have shown that from the early 13th century in France, the number and variety of poor people increased significantly. Famine was widespread in Europe between 1315 and 1317 (Lucas, 1930, pp. 376-377). Various contemporary writings, such as sermons, attest the situation, and contain images of paupers, dressed in rags, without shelter, money or food, some with physical disabilities, as the medieval mind tended to equate the sick and the poor, and begging on the street, at church and castle entrances-a stereotyped portrayal, perhaps, intended to move the faithful to acts of charity (Mollat, 1986, pp. 129-156), and often illustrated in books of hours (Guest, 1995, pp. 154-156, 161).

In the 14th century, on the one hand, Jean le Bon's ordonnances of 1351 and 1354 aimed to reduce vagrancy and to get all able-bodied people hired to work (Geremek, 1987, pp. 29-43). On the other hand, especially later in the century, crowds of paupers protested aggressively and violently, angered by the sight of the wealth of the

Glynnis M. Cropp, professor emeritus, School of Humanities, Massey University. 
nobility and powerful, and the inequitable distribution of goods. The real causes varied: disability, famine or war, depopulation and abandonment of a small village, excessive fiscal demands, and so on, all of which show the precariousness of survival and the social weakness of people without means and without the power to ward off poverty (Geremek, 1987, pp. 67-82; Geremek, 1994, pp. 169-184).

In the Roman de la Rose, Guillaume de Lorris (1966, pp. 14-15) created the classic medieval allegorisation of Pauvreté ("poverty"). On the wall of the garden are depicted forbidding personages who impede progress. The last of the series is Pauvreté: penniless, poorly dressed with an old sack as her outer garment, cold and trembling, she cowers in a corner because a poor person is always shameful and contemptible; the poor are destined never to be well fed, dressed, or shod, nor to be loved and esteemed (vv. 439-460). Christine de Pizan borrowed some of these traits in her depiction of Pauvreté in Le Livre de la Mutacion de Fortune (1959, pp. xiv-xviii, vv. 2561-2780). In his part of the Roman de la Rose, Jean de Meun (1970, pp. 56-57) stated in a discourse on poverty, the principle, probably derived from Seneca's thoughts on frugality and often attested in medieval moral writing, that poverty is generated by covetousness: “car soffisance fet richece/et couvoitise fet povrece./Soit rais, ou n’ait vaillant .ii. chiches/qui plus couvoite mains est riches” ("for sufficiency creates richness and covetousness creates poverty. Whether one is a king or has nothing of value, the more one covets, the less rich one is", vv. 18535-18538). Chaucer's (1951) Wife of Bath echoes this thought: "But truly poor are they who whine and fret/And covet what they cannot hope to get./And he that having nothing covets not/Is rich, though you may think he is a sot” (p. 314).

Besides those in extreme poverty, many other people, who eke out a meagre existence, plying a trade or skill, with a roof over their heads, are described as "poor”. For example, the poor old widow in Chaucer's "Nun's Priest's Tale", who lives in a cottage near a meadow, has three sows, three cows, a sheep called Molly, a rooster, and seven hens. With a meagre diet, she works hard (Chaucer, 1951, pp. 238-239). This is respectable poverty, such as the Wife of Bath defends, citing the authority of Seneca and Juvenal: "Though it be hateful, poverty is good,/A great incentive to a livelihood" (Chaucer, 1951, p. 314).

In addition to the widespread occurrence of this involuntary poverty, some virtuous, self-denying people voluntarily chose a life of poverty, usually with a sense of thus advancing in Christian spirituality and practising the virtues of patience and humility. The mendicant orders, the Franciscans and Dominicans, spread their teaching and example of evangelical poverty, and their exaltation of the spiritual value of poverty, when real poverty was increasing.

Relief of poverty was a Christian duty, incumbent on all, even on the poor, as is well exemplified in a fabliau "Le Vilain qui conquist paradis par plait” (“The Peasant who conquered paradise by pleading”; de Montaiglon \& Raynaud, 1878, pp. 209-214; Lorcin, 1979, pp. 149-150). The saints try and refuse a poor peasant entry to paradise, but eventually allow him to put his case to God: He has fed, clothed, and lodged the poor, cared for them until they died when he arranged their funerals, and thus he carried out his obligations as a good Christian; so, he pleads, in accordance with Christian teaching, he deserves to enter paradise. God recognises he has made a valid case and admits him.

\section{Examples of Involuntary Poverty in Courtly Literature}

In the literary world of courtliness and chivalry, involuntary poverty is depicted as temporary and susceptible to relief by virtue of courtly-chivalrous action. In the following three examples, it affects a lesser 
noble, a vavasseur, who holds a sub-fief from an overlord, women workers, and a knight without dependence on a lord. Goodness and beauty underlie the visible poverty of these characters.

In Chrétien de Troyes's romance Erec et Enide, Enide is the daughter of an elderly, handsome vavasseur, who explains to Erec that his poverty results from war and loss of land (de Troyes, 1966, vv. 510-511). The signs of poverty are that the household has only one servant (vv. 485-491), Enide and her mother are engaged in some kind of handwork, and Enide wears old, worn clothing, at variance with her amazing natural beauty and intrinsic nobility. When Erec has proved his valour, the vavasseur consents to his marriage with Enide. Still very poorly dressed, she arrives with Erec at king Arthur's court where queen Guinevere carries out a rags-to-riches transformation, enhancing Enide's natural, noble beauty (vv. 1532-1661). Erec fulfils his promise to her parents, sending them fine clothes, gold, and silver, and handing over to the vavasseur two castles in his father's kingdom (vv. 1797-1864). Thus their poverty is exchanged for material wealth, improved status, and power, as is evinced later at the coronation of Erec and Enide (vv. 6513-6517, 6540-6580), when Enide's parents rank among the nobility. Erec's prowess and generosity removed poverty.

In Chrétien de Troyes's romance Le Chevalier au lion, Yvain's encounter with three hundred captive women silk workers (de Troyes, 1952, pp. 142-146, vv. 5185-5346), contrasted immediately with a quintessential scene of noble courtly life (de Troyes, 1952, pp. 146-149, vv. 5347-5456), has acquired exemplary value in the history of medieval poverty for its socio-economic connotations. At the château de Pesme Avanture, in an enclosure, the young women work all day making silk and gold cloth. Their abject poverty and servitude are visible: (1) They are bareheaded, without girdles; (2) Their clothes are torn and dirty; (3) Their necks are thin and their faces pale from hunger; and (4) They weep as they work and are afraid at night to rest from fear of torment. Yvain quickly realises that in a more pleasant setting they would appear beautiful. Their spokesperson explains the history of their captivity by the two demons who hold the castle, and the low rate of weekly payment they receive for their work, one 60th of their total earnings, insufficient to feed and clothe themselves decently (vv. 5188-5337). Chrétien might have glimpsed exploitation of this kind, it has been suggested (Frappier, 1968, p. 156). By overcoming in combat the two devils, sons of a monster, Yvain frees the women, who return to their own land. His victory over evil liberates the intrinsically noble and beautiful young ladies from the bondage of shame and disgraceful poverty (vv. 5771-5809).

In the anonymous Breton lai of Graelent (Tobin, 1976, pp. 83-125), an angry queen maligns a knight, who has refused to be her lover on the grounds that his loyalty is to his lord, the king. She demands that the king cease payment and other support of the knight. He is therefore "povre" ("poor”, v. 151) and powerless to escape his marginality. A young townswoman gives him some equipment, including an old leather cloak, which makes people laugh at him (vv. 153-198). He rides on a nondescript horse into the forest, sees a beautiful young lady bathing with her two maids. He grabs her clothes. After declaring that he is not a second-hand dealer, he hands over her chemise ("undertunic") so that she can decently come out of the water. They become "amis" ("friends"). She gives the knight money, clothes, gold, and silver, on condition that he never reveals she is his beloved. He rewards those who helped him when he was poor and successfully pursues his career. Eventually, they cross the river into the Celtic other world. In this case, firstly the sympathy and generosity of a townswoman and then the mysterious and magic powers of the fée ("nymph") eliminate poverty imposed as unjustified punishment for honesty and loyalty. 
In these examples, involuntary poverty is described in material terms (clothes, equipment, and household); only the women captives suffer physically. Seigneurial largesse, knightly prowess, human compassion, and the mysterious Celtic supernatural are the means by which poverty is overcome. Christian charity and almsgiving are not mentioned here.

\section{Poverty as Disguise}

In two later romances, a kind of voluntary poverty, deliberately assumed for a short time, and superficial, is a narrative means, propelling the story. Disguise, or mask, is a familiar literary device for secret messages, spying, and gaining entry.

The first of these romances, L'Histoire du Chastelain de Coucy et de la Dame de Fayel (Jakemes, 1976), has six disguise episodes, four of which consist of disguise as a pauper. In one episode, a servant, dresses as a beggar waits at the castle gate for the regular distribution of food to the poor, then conveys the Chastelain's message to the Dame de Fayel, arranging a secret rendez-vous (vv. 2940-3186). In the second, another young man in disguise, employed by a rival lady, watches and follows the Chastelain to the Dame de Fayel's house. Mingling with the poor, a messenger and a spy complete their assignments, unidentified (vv. 3978-4072).

Twice the Chastelain adopts the disguise in order to enter the Dame de Fayel's house. In the first incident, at the lady's suggestion, he is kitted out as a poor pedlar with a basket-tray, heavy footwear, a thick smock, an old torn hat and a little iron rod to support his tray. His face is stained black, so that he is unrecognisable. After a night of pleasure, the Chastelain resumes his disguise and goes on his way (vv. 6520-6849).

In the second incident, disguised as a blind man, he is led into the castle by the Dame de Fayel's maid, who insists "ce povre aveugle" ("this poor blindman”) must be given bread. His clothes are torn, he carries a stick, and is unrecognisable (vv. 7182-7234).

All these ruses are part of an illicit love affair. There is no unmasking of the person disguised. In the first two instances, the disguise is simply expressed as “comme paillars” (v. 2964), or "en habit de paillart” (v. 3979), “dressed as a beggar, as a vagabond”, enabling a servant to merge into an anonymous crowd. The Chastelain's disguises are described in detail. He evinces no sense of demeaning himself. The love he shares with his lady and the need for secrecy, even when her husband is absent, justify the stratagems.

In the second romance, the Roman du comte d'Anjou, completed in 1316 by Jehan Maillart (1931, pp. iv-vi), the disguise of poverty binds the narrative. Three series of disguises, altogether nine episodes, expose different aspects of poverty and charity. The first two series concern the daughter of the Count of Anjou who escapes into the forest with a lady companion, to evade the shameful designs of her father; the third series concerns the Count of Bourges, who has married the Count of Anjou's daughter, lost her and their infant son, and is searching for them. Two women and a man, all unmistakeably noble and good-looking, adopt the disguise. They encounter other poor people, thus revealing different degrees of poverty and different attitudes to the poor.

The poverty assumed by the Count's daughter and her companion is relative to their aristocratic lifestyle. They escape into the forest at night, each carrying a casket of jewels, gold and silver, to avoid, it is stated, unaccustomed poverty (vv. 647-653); they wear cloaks over short garments as they will be walking through forest. Despite prayers for God's protection of “nostre povre vie” (“our poor life”, v. 1018), fear and hunger soon drive them to emerge and look for a town. 
In the first encounter, they receive help from a "bone fame” (v. 1070), a "preude fame” (v. 1081), a good woman, a worthy woman, who is poor, but has a house. She offers them coarse, stale, and black bread, which brings to the noble lady's mind a long list of the good things she ate in her father's house, and she weeps.

In the second, a poor widow, another "preudefame" (v. 1213), who has a house, offers more varied food: vegetable soup, eggs, black bread, and water, and provides scant modest bedding such as she has, and security. So, they stay, acquire equipment, and set about silk-making, to gain an honest living. Like the woman of the first episode, this "preudefame" perceives from the appearance and manners of the fugitives that they are of noble origin, and not truly poor. In other words, their disguise is faulted. And when some young men glimpse the beautiful lady and begin to pester her, they are obliged to move on (vv. 1698-1832).

The "povres fames esgareez" ("poor wandering women”, v. 1911), next encounter in the forest near Lorris a Chastelain, who directs them to his house, and continues on his way. His wife receives them angrily, misconstruing her husband's intentions and the young lady's beauty, envisaging the house becoming a brothel and her husband being unfaithful. On his return, he cannot placate her, so sends the two women to lodge in town with another good woman who offers much the same hospitality as they received in the previous two episodes, although supplemented by the Chastelain's gifts of food and wine. Their manners, work, and religious devotion make a good impression, as the Chastelaine hears, and they are invited to live at the castle at no expense, to teach the daughters their skills, enjoying a better lifestyle than in town "en un povre hostel” (“in poor lodgings”, v. 2275).

In this first series, successively three kind women help the fugitives according to their means. The Chastelaine, however, initially rejects the fugitives, not perceiving beauty and nobility under the veneer of poverty. By their industry they show how poverty can be reduced.

The lady's extraordinary beauty determines the turning point of the story. To be very brief, with her origins still unknown, she marries the Count of Bourges. While he is away at war, their son is born. Following treacherous interception and falsification of letters, the Count seems to have instructed that his wife and child be put to death. The servants charged with the task conspire to save them. The Countess is to remain outside the Count’s lands, "mendiant et querant sa vie” ("begging and seeking her livelihood”, v. 4325), "fame banie” (“a banished woman”, v. 4376). With a little money from the servants, she leaves for Etampes, where she can stay at the Ostel-Dieu for a fortnight, as she has recently given birth. Monastic hospitals served the poor and sick (Guest, 1995, pp. 169-171).

At Etampes, the Mayoress of the town takes the Countess and her infant home to wash, eat, and rest. Her husband, the Mayor, is angry about the expense entailed, so that the "essiliee", the banished woman, must leave, but with gifts from the Mayoress of a fur garment and some of her money, and advice to go to Orléans for the bishop's distribution of food to the poor, an event held three times weekly, for the soul of the bishop's brother. The irony is not lost on the Countess that the bishop's brother was the Count of Anjou, her father now deceased (vv. 4560-4574).

At Orléans she lodges with a trustworthy woman, "une fame ouvriere/de laine” ("a woman wool worker”, vv. 4592-4593), a spinner and weaver, who provides basic bedding, all she has. At the food distributions, the Countess stands among the poor, hiding her face to conceal her beauty. One day the Almoner questions her, sees her beautiful face, and is moved to pity. He directs her to the Ostel-Dieu, the 
infirmary, where she reveals to the Superior her suffering since her confinement, but not her origins and past. She is promised a fortnight's care.

In this second series of encounters, the Mayoress of a town, a poor working woman, the Almoner, and the Superior of a religious institution all help the destitute woman and infant. The mediation of the Church, in regular food distribution and in charitable care, is important. The only justification for a bishop to accumulate wealth was to give to the poor and needy.

Meanwhile, back from war, the Count of Bourges has discovered the horrendous wrong done to the Countess and his son. He sets out alone, in bondsman's clothes, sandals, a hooded cloak, and carrying a staff (v. 5298), he will look for his wife and child among the poor and beg for food, as though he is a mendicant penitent, actively seeking alms.

He walks towards Etampes, scratched by rocks and thorns. He meets a hideous, uncouth peasant who curses him, then a priest who gives him some black bread. He sleeps outdoors; he wards off dogs that always dislike the poor, it is said; he weeps and sighs. He receives curses from some, and compassion from others (vv. 5470-5616). Then the Mayoress appears. Moved by his tears and rags, she questions him, he confides in her and, of course, she directs him towards Orléans. He goes on his way, footsore and complaining about the wind and cold.

He reaches Orléans in time for the food distribution, which is described with more detail: 16 thousand poor (a grossly inflated number, even in medieval counting for the total population of the town probably numbered fewer than 20,000) form a crowd controlled by more than thirty guards with rods and truncheons. Mass distributions of this kind are attested (Geremek, 1987, p. 189; Geremek, 1994, pp. 40-41). The Count keeps moving through the throng, and so is hit more than once by the guards. He finally comes to the attention of the Almoner, to whom he relates the purpose of his search, without revealing identities. The Almoner directs him to the Ostel-Dieu and its Superior. Reunion with the Countess and his son is happily achieved and her identity at last revealed. The Mayoress and the Superior are amply rewarded.

The third series of episodes describes a man's experience of assumed poverty. He sets out in a state of more abject poverty than that of the lady and her companion. He feels acutely the physical pain and hardship, and encounters public contempt and hostility. Altogether the three series offer a glimpse of varying states of poverty and different treatment of the poor, thus showing the ambiguity present in certain medieval attitudes to poverty.

\section{Conclusions}

Poverty, or "income inadequacy", a term adopted these days by government ministries, is depicted in these literary examples in material terms: clothes, food, and bedding especially. Absent from this literature are the worst manifestations of poverty: crime, physical disabilities (although one character pretends to be a blind pauper), and other repulsive features: smell, dirt, ugliness, and lack of sanitation. The conventional opposition of rich and poor has been replaced by the paradox that the visible, external signs of poverty do not conceal natural beauty and intrinsic nobility. Knightly prowess, seigneurial largesse, the charitable institutions of the Church, the hospitality and good will of others, even of the very poor, as well as the practical skills and active role of women, are means of relieving the pain and shame of poverty and re-integrating in society the marginalised poor. 


\section{References}

Chaucer, G. (1951). The Canterbury tales. (N. Coghill Trans.). Harmondsworth: Penguin.

de Lorris, G., \& de Meun, J. (1966-1970). Le Roman de la Rose (Vols. 1-3). F. Lecoy (Ed.). Paris: H. Champion.

de Montaiglon, A., \& Raynouard, G. (Eds.). (1872-1890). Recueil général et complet des fabliaux des XIII et XIV siècles (Vols.

1-6). Paris: Jouast; New York: B. Franklin.

de Pizan, C. (1959-1966). Le Livre de la mutacion de fortune (Vols. 1-4). S. Solente (Ed.). Paris: Picard.

de Troyes, C. (1952). Yvain (Le Chevalier au lion). T. B. W. Reid (Ed.). Manchester: Manchester University Press.

de Troyes, C. (1966). Les Romans de Chrétien de Troyes. I. Erec et Enide. M. Roques (Ed.). Paris: H. Champion.

Frappier, J. (1968). Chrétien de Troyes. Paris: Hatier.

Geremek, B. (1987). The margins of society in late medieval Paris. (J. Birrell Trans.). Cambridge: Cambridge University Press.

Geremek, B. (1994). Poverty: A history. (A. Kolakowska Trans.). Cambridge, M.A.: Blackwell.

Guest, G. B. (1995). A discourse on the poor: The hours of Jeanne d'Evreux. Viator, 26, 153-180.

Jakemes. (1976). L'Histoire du chastelain de Couci et de la dame de Fayel. G. A. Crapelet (Ed.). Geneva: Slatkine.

Lorcin, M.-Th. (1979). Façons de sentir et de penser: les fabliaux. Paris: Champion.

Lucas, H. S. (1930). The great European famine of 1315, 1316, and 1317. Speculum, 5, 343-377.

Maillart, J. (1931). Le Roman du comte d'Anjou. M. Roques (Ed.). Geneva: Droz.

Mollat, M. (1986). The poor in the Middle Ages: An essay in social history. (A. Goldhammer Trans.). New Haven: Yale University Press.

Tobin, P. M. (1976). Les Lais anonymes des $12^{e}$ et $13^{e}$ siècles: édition critique de quelques lais bretons. Geneva: Droz. 